tance of providing sufficient incentives for research and development in the private sector is emphasized by the fact that about 85 per cent of the development part of $\mathrm{R} \& \mathrm{D}$ is performed by private industry, chiefly with financial support from the companies themselves.

Maurice H. Stans, Secretary of Commerce, left the subcommittee with a few suggestions to chew over, however. "We should examine," he said, "the feasibility of establishing a single federal focus for several activities directly related to enhancement, assessment, and forecasting of industrial technology." This suggestion is an echo of an old cause of the subcommittee's, which held a number of hearings last year under the former chairman, Emilio Q. Daddario, to explore the feasibility of setting up an Office of Technology Assessment, and which has recently been putting that into effect.

The second option suggested by $\mathrm{Mr}$ Stans is that the committee should carefully consider the feasibility of creating direct or indirect financial incentives to stimulate new technology. Federal assistance could be provided to private companies-for example by loan guarantees, cost sharing, grants or procurement incentives, and the risk of setting off to develop a new technology could also be offset to some extent by tampering with the tax structure, giving depreciation allowances, and a host of other indirect subsidies. And, taking a sideways glance at his own National Bureau of Standards, Mr Stans suggested that there could be considerable tightening up on the setting of industrial standards. "Potential manufacturers," he said, "hesitate to invest heavily in the introduction of innovative equipment when they are uncertain about the requirements or specifications which will define the market for such equipment, especially in export trade."

But voluntary standards made by private industry are likely to fall foul of the anti-trust laws. Although the overt reason for the anti-trust laws is to prevent the formation of cartels and similar price-fixing rings, they can also have the effect of slowing research and development, for with the exception of a few special cases it is illegal for companies to collaborate on research projects. Mr Stans suggested that "it may well be time to modernize the anti-trust laws which evolved to deal with the different problems of an earlier era in order to permit the pooling of funds and risks that must accompany major technological advances". He was also quick to point out when questioned by the committee that it is premature to draw the conclusion that changes in the laws are on the way. Nevertheless, it seems clear that in areas such as research and development on pollution control, some relaxing of the anti-trust laws is being considered at least in the Department of Commerce.

$\mathrm{Mr}$ Stans told the subcommittee that in some areas American companies are being hamstrung by the anti-trust laws in such a way that they find it difficult to compete on equal terms with joint research projects conducted by their foreign competitors. But at home the anti-trust laws are increasingly becoming a source of concern for the smaller motor manufacturers who must meet stringent exhaust emission standards by 1975.

Mr Leonard Woodcock, president of the International Union, United Automobile, Aerospace and Agricultural Implement Workers of America (the union which represents most of the motor workers in the United States), wrote to $\mathrm{Mr}$ John $\mathrm{N}$. Mitchell, the Attorney General, on May 24 suggesting that unless a crash programme com. bining the resources of all manufacturers in the automobile industry is conducted, the problem of exhaust pollution may not be solved before the 1975 deadline, and moreover, many of the smaller automobile companies are likely to go to the wall simply because they have insufficient funds to invest in pollution research. "This cooperative effort," he said, "can be maintained within both the spirit and the letter of our anti-trust laws." But Mr Richard McLaren, Assistant Attorney General in the Anti-trust Division, did not agree, for in reply to Woodcock's letter he said "we cannot agree... with your statement that there should not be competition in such vital areas as human safety and pollution control. Competition has served us well as a spur to the enormous technological gains achieved in this and previous decades. It should not be abandoned as we strive to meet the critical challenges to the safety and health of American citizens".

Perhaps the best explanation of the policy of the Department of Justice towards collaboration on pollution research was given by $\mathrm{Mr}$ McLaren in a letter to $\mathrm{Mr}$ John $\mathrm{A}$. Volpe at the Department of Transportation, when he said "the Department of Justice feels that government agencies which are charged with the responsibility of meeting specific public goals, such as promoting automobile safety, should proceed in a manner which promotes competition to a maximum extent consistent with the achievement of their specific statutory responsibilities". Obsolete or not, the anti-trust laws are plainly a fundamental part of the American industrial ethos.

\title{
Pesticides in the Open
}

A MUCH criticized obstacle to the free flow of scientific information about pesticides and herbicides was removed last week by $\mathrm{Mr}$ William $\mathrm{D}$. Ruckelshaus, Administrator of the Environmental Protection Agency. The EPA has now decided to release scientific advisory reports on controversial pesticides as soon as it receives them. The reports, which often constitute an important part of the mechanism by which an allegedly dangerous agent is banned or allowed for use, have in the past been kept secret until a final decision is taken. This has made it impossible for the scientific information contained in the reports to be criticized or discussed by professional scientists until it is too late to affect the final decision.

The scientific advisory reports are filed under the provisions of the Federal Insecticide, Fungicide and Rodenticide Act, which allows a manufacturer of a product whose use has been cancelled by the EPA to request that the issue be referred to an advisory committee or to ask for a public hearing. This procedure can delay cancellation by six months or more, for the manufacturer has 30 days after the serving of a cancellation notice to request referral to the advisory committee and the committee, whose members are nominated by the National Academy of Sciences, has 60 days in which to make its report. Within 90 days, Mr Ruckelshaus must then decide either to confirm or to set aside his earlier notice of intention to cancel or suspend the product. During the whole of these proceedings, the manufacturer is allowed to market the product.

The issue of secrecy has been brought into sharp focus recently with the controversy surrounding a report on the herbicide $2,4,5-\mathrm{T}$, which was submitted to Ruckelshaus in May. A few copies of this have found their way into circulation, and it has come in for strong criticism from some sectors of the scientific community. One of the charges levelled at the report is that the scientific information which it contains would not be acceptable for publication in a scientific journal, because some of it is based on superficial experiments conducted without proper controls. That information will, however, now be open to criticism, for the 2,4,5-T report is available from the EPA upon request. 